\title{
Impact of small-scale hydropower stations on macroinvertebrate communities for regulated rivers
}

\author{
Yasmina Martínez, David Gutiérrez, Romina Álvarez-Troncoso* and Josefina Garrido \\ Departamento de Ecoloxía e Bioloxía Animal, Facultade de Bioloxía, Universidade de Vigo, Campus \\ Lagoas-Marcosende s/n 36310 Vigo, España. \\ * Corresponding author: ralvareztroncoso@gmail.com
}

Received: 25/09/18 Accepted: 26/08/19

\begin{abstract}
The impact of small-scale hydropower stations on macroinvertebrate communities measured using historical data for regulated rivers in Galicia (NW Spain)

Despite the fundamental importance of hydroelectric power for socioeconomic development, the presence of hydropower plants cause large-scale alterations to the natural flow regime of rivers and profoundly influences aquatic processes and biodiversity. This study evaluates the seasonal impact of small hydropower stations by analysing and measuring macroinvertebrate community composition. Our objectives were to (1) examine whether the abundance and richness of benthic macroinvertebrates vary according to alterations to the river, (2) identify the families of macroinvertebrates most sensitive to depletion as a consequence of the impact of a hydropower station, and (3) determine whether there is a seasonal component in river regulation that impacts on macroinvertebrate communities. A 167848 individuals were sampled from 6 different phyla and 10 different orders of Arthropoda representing 116 different macroinvertebrate families, whose distribution and abundance depended on the river, sampling time and sampling site. Ephemeroptera, Diptera, Trichoptera, Coleoptera and Plecoptera were the most representative orders in all seasons of the year, and also had the most abundant families (Baetidae, Caenidae, Chironomidae and Simuliidae). There was no great variation in autumn and winter for the most abundant taxa but it was important variation in spring and summer. Our findings point to differences in macroinvertebrate abundance and richness in aquatic systems impacted by hydropower stations and to a recovery process downstream, where the water level and habitats are not negatively affected by these stations.
\end{abstract}

Key words: hydropower station, rivers, macroinvertebrates, monitoring, Galicia, taxonomy

\section{RESUMEN}

Impacto de las centrales hidroeléctricas de pequeña escala en las comunidades de macroinvertebrados

A pesar de que la energía hidroeléctrica es fundamental para el desarrollo socioeconómico, la presencia de las estructuras hidroeléctricas provoca, a gran escala, alteraciones en el régimen fluvial natural de los ríos, influyendo profundamente en los procesos acuáticos y en su biodiversidad. Este estudio compara la composición de la comunidad de macroinvertebrados y las métricas de su estructura para evaluar el impacto estacional que ejercen sobre la misma las minicentrales hidroeléctricas. Nuestros objetivos fueron examinar si (i) la abundancia y la riqueza de macroinvertebrados bentónicos muestran una relación con las alteraciones en el río, (ii) las familias más sensibles de macroinvertebrados se vieron mermados por el efecto de la minicentral y (iii) el posible efecto de la regulación de los ríos tiene un componente estacional sobre las comunidades de macroinvertebrados. Se muestrearon 167848 individuos de 6 filos y 10 órdenes diferentes de Artrópodos que representaban 116 familias diferentes de macroinvertebrados, cuya distribución y abundancia dependia del rio, la estacionalidad y el sitio de muestreo. Los Ephemeroptera, Diptera, Trichoptera, Coleoptera y Plecoptera fueron los más representativos en todas las estaciones del año, y también presentaron las familias más abundantes (Baetidae, Caenidae, Chironomidae y Simuliidae). No hubo grandes variaciones en otoño e invierno para los taxones más abundantes, pero sí en primavera y verano. Nuestros hallazgos apuntan a diferencias en la abundancia y riqueza de macroinvertebrados en los sistemas acuáticos afectados por las centrales hidroeléctricas y un proceso de recuperación aguas abajo, donde el nivel del agua y los 
hábitats no se ven afectados negativamente por estas estaciones.

Palabras clave: minicentral hidroeléctrica, ríos, macroinvertebrados, monitoreo, Galicia, taxonomía

\section{INTRODUCTION}

Freshwater ecosystems provide vital resources for humans and represent the sole habitat for an extraordinarily rich, endemic and sensitive biota (Göthe et al., 2015). The fact that streams and rivers are used by humans for many different purposes (e.g., hydroelectric power, irrigation, navigation, recreation, industry) has severe consequences for biota due to vulnerability to flow modifications, habitat degradation and water pollution (Göthe et al., 2015).

Currently, a major problem with rivers is that their flow is regulated by structures such as hydropower stations. Globally, small and large hydropower plants are by far the largest generator of renewable electricity (World Energy Council, 2010; Singh et al., 2015), providing $19 \%$ of the planet's electricity in 2015 (Singh et al., 2015). Interest in hydropower is increasing, especially in small-scale hydropower installations, which have emerged as an easily developed and inexpensive energy source (Paish, 2002; Singh et al., 2015). In most cases, these stations are run-of-river schemes, which are broadly considered to be less environmentally damaging than other hydropower systems (Anderson et al., 2015; Singh et al., 2015). In a run-of-river hydropower station, the natural channel is blocked by a dam in such a way that only part of the river flow is diverted to a secondary (bypass) channel to feed the turbines that generate electricity, after which the water is returned to the natural river channel via a downstream tailrace (Anderson et al., 2015).

However, evidence to support the argument of less environmental damage is scarce (Abbasi \& Abbasi, 2011); in fact, according to Fuentes-Bargues \& Ferrer-Gisbert (2015) many authors confirm that this type of infrastructure does have an impact on the natural environment, with the main threats listed as disruption of longitudinal connectivity, habitat fragmentation, inadequate environmental flow and monthly distribution, physical habitat alteration, mortality of fish due to turbines and lack of control over environmental flow (Kucukali \& Baris, 2009; Anderson et al., 2015).

There is, therefore, an urgent need to review current understanding of small-scale hydropower schemes, particularly in the UK and the EU, where a huge uptick in hydropower development has been prompted by EU subsidies, national renewable energy legislation (Kucukali \& Baris, 2009) and compliance with the EU Water Framework Directive (WFD; 2000/60/EC), which focuses on the conservation of a good ecological status in all waterbodies and aquatic ecosystems through compliance with ecological reference conditions. Periodic studies are therefore necessary in order to determine the status and water quality of aquatic ecosystems (Funk et al., 2017).

Crucial to such studies are biological communities, and especially benthic macroinvertebrates, widely used as bioindicators because of their ubiquity and sedentary nature (which enables spatial analyses of pollutants), their relatively long life cycles (which elucidate temporal changes) and their constant exposure to water (which enables detection of disturbances that cannot usually be detected by chemical analyses). Benthic macroinvertebrates also play a crucial role in the transport and use of energy in their ecosystems (Armitage et al., 1983; Ferreira et al., 2011; Pérez-Bilbao et al., 2013).

Bearing in mind the above-mentioned alterations to regulated rivers, a negative impact on macroinvertebrate communities can be expected from even small hydropower stations, most particularly a decrease in the numbers of the most sensitive families in more intensely disturbed areas (Prat et al., 2009) in the middle sections of rivers, where dams interrupts longitudinal connectivity and causes river fragmentation (Álvarez-Troncoso et al., 2015, Anderson et al., 2015).

Another issue is that there may be a seasonal component in the possible impact of small hydro- 


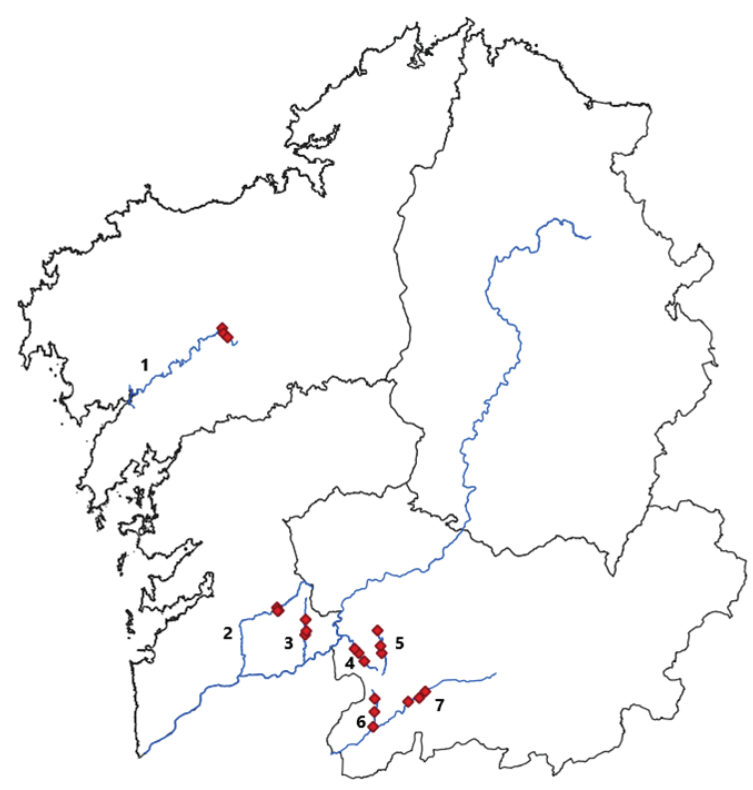

Figure 1. Location of the rivers and sampling sites (Galicia). 1-Tambre; 2-Tea; 3-Deva (PO); 4-Deva (OU); 5-Tuño; 6-Fragoso; 7-Limia. Red boxes indicate sampling locations. Esquema de la localización de los ríos y los puntos de muestreo (Galicia). 1-Tambre; 2- Tea; 3- Deva (PO); 4-Deva (OU); 5- Tuño; 6-Fragoso; 7-Limia. Los cuadrados rojos indican las locaciones de los muestreos.

power stations. Macroinvertebrate communities may be affected differently depending on the time of year (Jesús et al., 2004), as each season is associated with different hydromorphological, physicochemical and climatological conditions that impact on their abundance (Urbanič, 2014). We would expect the impact to be greatest in summer because this is when rainfall is scarce and river flow is lowest, especially in rivers located in the interior, which in Mediterranean-type climates, are characterized by hot dry summers. Any changes produced by a hydropower station can therefore be expected to be more severe and to affect the structure of benthic macroinvertebrate communities to a greater extent. Therefore, several authors have chosen this macroinvertebrate group as an object of study, including Benetti \& Garrido (2010), Benetti et al. (2012), Pérez-Bilbao et al. (2013), Álvarez-Troncoso et al. (2014), Álvarez-Troncoso et al. (2015) and Álvarez-Troncoso et al. (2017).
Meriting particular mention in this context is the region of Galicia (northwest Spain), as given the density of its fluvial network (Pérez-Alberti, 1986), its rivers are increasingly attracting the attention of the electricity supply industry, which, in turn, is raising environmental concerns about overexploitation of the corresponding water resources.

The aim of this study was to analyse how the relationship between the abundance and richness of benthic macroinvertebrates vary according to alterations to the rivers in Galicia (1-Tambre; 2-Tea; 3-Deva (PO); 4-Deva (OU); 5-Tuño; 6-Fragoso and 7-Limia) and to identify the families of macroinvertebrates most sensitive to depletion as a consequence of the impact of a hydropower station. Our goal was also to determine whether there is a seasonal component in river regulation that impacts on macroinvertebrate communities. Our focus was also to examine whether the abundance and richness widely used in ecosystem assessment and monitoring due to their simplicity (Feld et al., 2014) of benthic macroinvertebrates vary according to alterations to the river, identifying the families of macroinvertebrates most sensitive to depletion as a consequence of the impact of a hydropower station, and to determine whether there is a seasonal component in river regulation that impacts on macroinvertebrate communities.

\section{MATERIALS AND METHODS}

\section{Study area and sampling periods}

The study was carried out on 7 rivers in Galicia (Fig. 1): Deva-Pontevedra (Deva-PO), DevaOurense (Deva-OU), Fragoso, Limia, Tea, Tuño and Tambre. The first 6 rivers, located in southern Galicia, correspond to the Miño-Sil Hydrographic Confederation, a region characterized by mild winters and cool summers, humid air, abundant clouds and frequent rainfall throughout the year (BOE, 2016). The Tambre river, located in northwestern Galicia, belongs to the Galician Coast Hydrographic Demarcation, characterized by a warm and humid climate and some zones with very abundant rainfall (BOE, 2016). Despite climate and geological differences within the 
Table 1. List of rives, sampling times, sampling points, types, codes and groups. Lista de los ríos, la época de muestreo, las estaciones de muestreo de cada río, el tipo de localización, el código y el grupo al que pertenece dicho punto.

\begin{tabular}{|c|c|c|c|c|c|}
\hline River & Sampling time & Sampling point* & Sample type & Our code & \\
\hline \multirow{3}{*}{ Deva-PO } & Autumn (2001). & DEPO1 & Control & V1 & \multirow{3}{*}{$\mathrm{G} 2$} \\
\hline & Winter. Spring and & DEPO2 & Dam area & $\mathrm{V} 2$ & \\
\hline & Summer (2002) & DEPO3 & Downstream & V3 & \\
\hline \multirow{3}{*}{ Deva-OU } & Autumn (1998). & Retortoiro & Control & D1 & \multirow{3}{*}{$\mathrm{G} 2$} \\
\hline & Winter. Spring and & Lavandeira & Dam area & D2 & \\
\hline & Summer (1999) & Pena do Bugallo & Downstream & D3 & \\
\hline \multirow{3}{*}{ Fragoso } & \multirow{3}{*}{$\begin{array}{l}\text { Spring (2015) and } \\
\text { Autumn (2016) }\end{array}$} & Parada do Monte & Control & $\mathrm{F} 1$ & \multirow{3}{*}{ G2 } \\
\hline & & Ponte Abeleda & Dam area & $\mathrm{F} 2$ & \\
\hline & & Grou & Downstream & F3 & \\
\hline \multirow{3}{*}{ Limia } & Winter. Autumn. & VP1 & Control & L1 & \multirow{3}{*}{ G1 } \\
\hline & Spring and & VP2 & Dam area & $\mathrm{L} 2$ & \\
\hline & Summer (2003) & VP3 & Downstream & L3 & \\
\hline \multirow{3}{*}{ Tea } & \multirow{3}{*}{$\begin{array}{c}\text { Winter. Spring and } \\
\text { Summer (1999) }\end{array}$} & Redondo I & Control & E1 & \multirow{3}{*}{ G1 } \\
\hline & & Redondo II & Dam area & E2 & \\
\hline & & Pereiras & Downstream & E3 & \\
\hline \multirow{3}{*}{ Tuño } & Autumn (1998). & San Martiño & Control & $\mathrm{U} 1$ & \multirow{3}{*}{$\mathrm{G} 2$} \\
\hline & Winter. Spring and & Trasmiras & Dam area & $\mathrm{U} 2$ & \\
\hline & Summer (1999) & Ponte Madeiros & Downstream & U3 & \\
\hline \multirow{3}{*}{ Tambre } & Spring. Summer. & Ponte Abalar & Control & $\mathrm{T} 1$ & \multirow{3}{*}{ G1 } \\
\hline & Autumn (1998) & Fecha & Dam area & $\mathrm{T} 2$ & \\
\hline & and Winter (1999) & Bachao & Downstream & $\mathrm{T} 3$ & \\
\hline
\end{tabular}

* The sampling points are the labels used to name the places where sampling was done in previous studies of these rivers. Included here merely to facilitate cross-referencing with those other studies.

study area, all the rivers are categorized as siliceous Cantabric-Atlantic axis rivers (BOE, 2016). The dominant vegetation in the study area consists of Quercus robur L., Corylus avellana L., Ulmus minor Mill, Fraxinus angustifolia Vahl, Alnus glutinosa Gaertn and Cornus sanguinea L., all of which combine to form a generally well-preserved riparian forest (Carballeira et al., 1983).
The data used for our study, was taken from previous campaigns carried out between 1998 and 2016, to analyse rivers (1-Tambre; 2-Tea; 3-Deva (PO); 4-Deva (OU); 5-Tuño; 6-Fragoso and 7-Limia) status throughout all seasons of the year (Béche et al., 2006). Table 1 lists the sampling times (the 4 seasons of the year in almost all cases) and sampling sites (control, 
Total flow Majority of flow 맴 Minority of flow

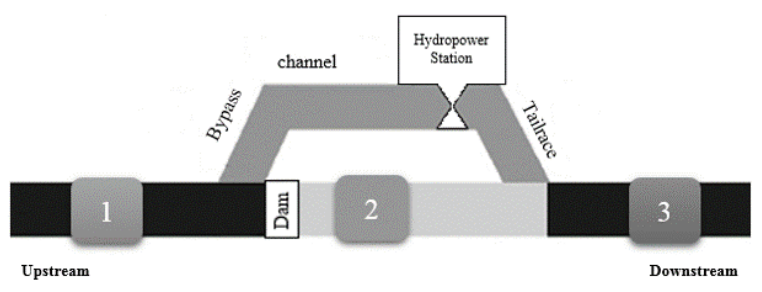

Figure 2. Diagrammatic representation of sampling in relation to the run-of-river hydropower station layout. 1-Control site; 2-Dam area site; 3-Downstream site. Diagrama de representación de los puntos de muestreo en relación a la central hidroeléctrica. Punto de control (1), zona de la presa (2) y aguas abajo de la presa (3).

dam area and downstream) with their assigned alphanumeric codes. Regarding sampling times, macroinvertebrate communities were analysed for all 7 rivers in spring and for 6 of the 7 rivers in the remaining seasons (the Fragoso was excluded in summer and winter and the Tea was excluded in autumn) for a total of 25 seasons. As for sampling sites, 3 were selected in relation to the location of the hydropower station in each river (Fig. 2): the control site was located around $1 \mathrm{~km}$ upstream from the dam in an unaltered area where no changes in stream flow were observed; the dam area site was located at less than $1 \mathrm{~km}$ downstream from the dam, expected to be the most affected area; and the downstream site was located at least $1 \mathrm{~km}$ downriver from the station and tailrace to check if natural conditions were recovered (and if not, a conservation and restoration plan would be developed). In total, 75 samples were obtained ( 25 sampling times by 3 sampling sites for each river). While several factors could potentially influence differences between the macroinvertebrate communities, such as the river location and its characteristics, the dam pressure and even seasonal conditions, the main differences between the studied rivers were size and flow (Lobera et al., 2016). To check if there were any differences due to location, the larger Tambre, Tea and Limia rivers were placed in Group 1 for comparison with the smaller Deva-PO, Deva-OU, Fragoso and Tuño rivers, placed in Group 2.

\section{Sampling of macroinvertebrates}

The most frequent substrates in the sampled rivers were sand (to $2 \mathrm{~mm}$ ), pebbles (2-200 $\mathrm{mm}$ ), moss and macrophytes. Macroinvertebrates were kick-sampled using a hand-net $(25$ X $25 \mathrm{~cm}$ aperture, $60 \mathrm{~cm}$ deep, $100 \mu \mathrm{m}$ mesh) and a Surber sampler $(25$ X $25 \mathrm{~cm}$ aperture, $60 \mathrm{~cm}$ deep, $500 \mu \mathrm{m}$ mesh). According to this semi-quantitative multi-habitat sampling method, 20 kicks were distributed proportionally in the most frequent habitat types (Alba-Tercedor et al., 2005). Bearing in mind that a kick is a sampling unit (requiring the substrate to be moved with the feet and hands) located $50 \mathrm{~cm}$ from the net opening, allowing $25 \mathrm{~cm}$ on each side the area covered for each kick sample is $0.125 \mathrm{~m}^{2}$ and, given that 20 kick samples were taken at $100 \mathrm{~m}$ intervals, the total sampled area was $2.5 \mathrm{~m}^{2}$ per sampling site (Alba-Tercedor et al., 2005).

The samples for each substrate were pooled and preserved in $4 \%$ formaldehyde solution to avoid the action of carnivores (Alba-Tercedor et $a l ., 2005)$. Once in the laboratory, the macroinvertebrates were identified at family level according to standard entomology procedures, using a stereomicroscope, a binocular microscope and reference works, including Tachet et al. (2003) and Álvarez-Troncoso et al. (2014). After identification, the specimens were preserved in $70 \%$ alcohol and deposited in the scientific collection of the Laboratory of Aquatic Entomology at Vigo University, Spain.

\section{Statistical analyses}

To assess macroinvertebrate community differences between different sampling times and sites in terms of the influence of the dams, we used non-parametric multidimensional scaling analysis (nMDS) and a Bray-Curtis similarity matrix to visualize differences in macroinvertebrate family compositions between sites in the different seasons. MDS is an iterative ordination method that preserves the rank-ordered distances between observations in the ordination space, while rearranging observations to minimize the measure of disagreement (called 'stress') between 
compositional dissimilarities and the distance between points in the ordination diagram (Kruskal, 1964).

Taxa abundance data for the sites for spring 1998 and summer 2003 were analysed and compared. Samples and results available for this study from that periods were selected for carrying out the analysis.

A similarity percentage (SIMPER) analysis and Bray-Curtis similarity were used to determine the taxa contributing most to dissimilarities between sites (total abundance of invertebrates for each site at the different sampling times). The SIMPER analysis estimated the contribution of each species to differences between river basins and sites. Species were only included in the SIMPER analysis if they contributed more than 2.5 $\%$ to dissimilarity (Clarke \& Warwick, 2001).

A permutational univariate analysis of variance (PERMANOVA, two way), based on the Bray Curtis similarity index and 9999 permutations, was used for pairwise testing (for differences between sampling events for total number of individuals, seasonal and annual patterns). There are significant differences when $p<0.05$. All statistical tests were performed using PAST software (Hammer et al., 2001).

\section{RESULTS}

A 167848 individuals were sampled from 6 different phyla and 10 different orders of Arthropoda representing 116 different macroinvertebrate families, whose distribution and abundance depended on the river, sampling time and sampling site. Below we describe the patterns associated with each hydropower station and each season.

Figures $3 \mathrm{a}$ and $3 \mathrm{~b}$ depict general and relative abundance results. Ephemeroptera, Diptera, Trichoptera, Coleoptera and Plecoptera were the most representative orders in all seasons of the year, and also had the most abundant families (Baetidae, Caenidae, Chironomidae and Simuliidae). There was no great variation in autumn and winter for the most abundant taxa (Ephemeroptera, Diptera and Trichoptera), with an average of 7000 individuals per taxa. In contrast, the difference in spring was notable, especially for Ephemeroptera, with some 26000 individuals, following by Diptera (around 10000 individuals) and Coleoptera and Trichoptera (around 4000 individuals each). In summer, Diptera, with 21000 individuals, was the most representative group, followed by Ephemeroptera (around 9000 individuals) and Trichoptera (around 8000 individuals).

Since the most abundant taxa, Ephemeroptera, Trichoptera and Plecoptera, include communities that are especially sensitive to environmental impact (Feld et al., 2014), we explored whether these sensitive families were affected differently by the hydropower stations according to the seasons of the year. Figure 4 depicts the percentage of sensitive families that scored more than 6 (of a maximum of 10) according to the IBMWP
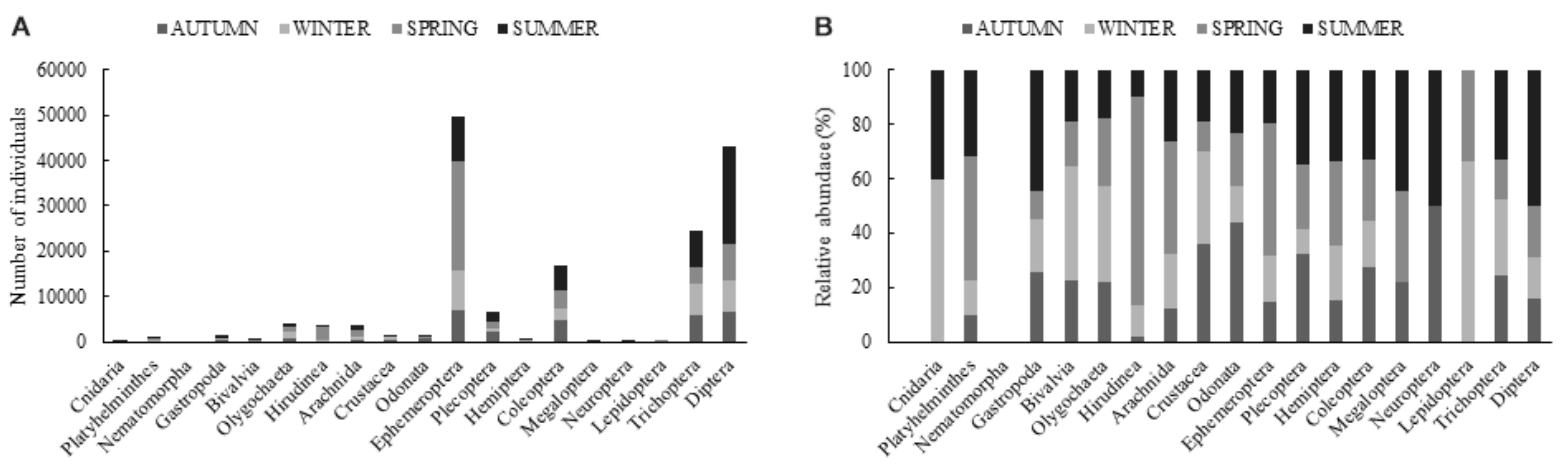

Figure 3. Number of total individuals in each macroinvertebrate taxon according to the season (a) and relative numbers of individuals in each macroinvertebrate taxon according to the season (b). Número total de individuos de cada taxón de macroinvertebrados según la estación del año (a) y Número relativo de individuos de cada taxón de macroinvertebrados según la estación del año (b). 


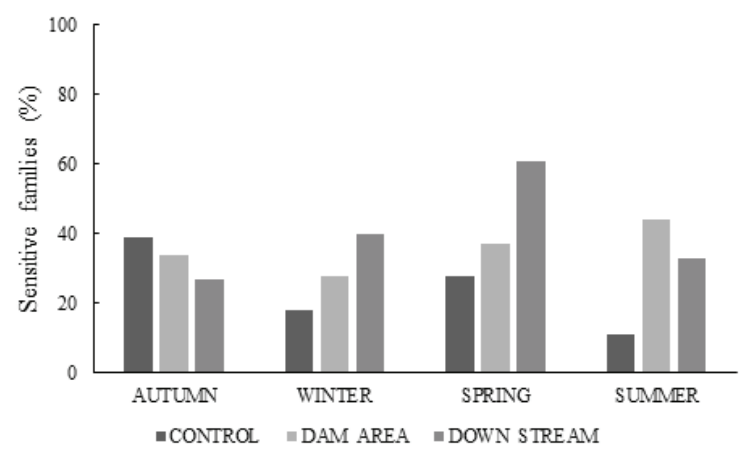

Figure 4. Percentages of the most sensitive macroinvertebrate families by season and sampling sites (control, dam area and downstream). Porcentaje de las familias de macroinvertebrados más sensibles frente al total en función de la época del año y el punto de muestreo: aguas arriba de la presa (control) zona de la presa y aguas abajo de la presa.

(Iberian Monitoring Working Party) scoring table (Alba-Tercedor, 1996). This selection was made in order to collect the most sensitive families of the area to check if they are or not affected by the alterations. The families with highest score value for IBMWP (10) more abundant in the results in all the seasons were Heptageniidae and Brachycentridae especially in downstream site; Leptophlebiidae more abundant especially in dam site and Leuctridae more abundant in control site.

Regarding the patterns associated with each season and each sampling site (Fig. 5), some differences were observed in autumn and winter, 3 of the 5 most abundant families were represented in all the sites, namely, Baetidae, Chironomidae and Elmidae. In spring and summer the pattern was quite different, as the 5 most abundant families were represented in all the sites; in spring, Baetidae, Chironomidae, Enchytraeidae, Ephemerellidae and Leptophlebiidae, and while in summer, Baetidae, Chironomidae, Dytiscidae, Elmidae and Simuliidae were the most abundant families. We selected a maximum of 5 families from the most abundant taxa in order to collect the most representative elements of the rivers. The results are similar to others in the literature (Garcia-Roger et al., 2011), according to other researchers and as it was expected, the most ubiquitous taxa were also the most abundant (e.g., Chironomidae, Leuctridae and Baetidae). These families are very common in the region and represent the general conditions of the basin. Some authors associated that Baetidae, Leuctridae and Simuliidae are characteristic of perennial streams and are also indicative of the riffle mesohabitat (Garcia-Roger et al., 2011).

Patterns for metrics such as species richness, IBMWP score and Shannon's, Simpson's and Margalef's indexes were similar (Fig. 6). Figure 6 is organized according to location (Tambre, Limia, Tea from group 1 and Tuño, Deva OU, Deva PO and Fragoso) of the sites (1-Control, 2-Dam site and 3-Downstream) and also the groups (group 1 and group 2) of rivers. Values obtained for all the indexes in autumn were quite similar, with small increases in group 1 sites (T1, L2, L3) control, dam and downstream locations and group 2 sites (D1, F1 and F3) control and downstream location (Fig. 6). In winter and spring, the IBMWP index scores were higher in L2, L3, D1, V2 and V3 and diversity values were lower in L3. In summer, the values for this index were higher in L2, L3, D1 and V3 and diversity was consequently higher in L3 and E3.

To corroborate the possible impact of the hydropower stations on macroinvertebrate communities, we compared the control, dam area and downstream sampling sites in 4 nMDS plots (one per season), based on a distance matrix computed with any of 21 ( 7 rivers X 3 sampling sites each) supported distance measures. The relative positions of site curves of nMDS plots indicated similarities, as those closer to one another were likely to be more similar (Fig. 7). The plots showed that in autumn and winter almost all the sites were similar. The exception was site L1 (Limia control) where the plots showed greater distances compared to other sites due to factors other than environmental impact. Stress values are quite high in autumn (above 0.20; see Fig. 7a), indicating that that plot represent very poorly the differences between macroinvertebrate communities. In spring and summer there were greater differences between sites; sites located in the dam area, i.e., F2, D2 and T2, and downstream, i.e., F3, D3 and T3, were very similar to each other and different from the other sites. In general, there were more similarities between the Fragoso, Deva and Tuño rivers. 


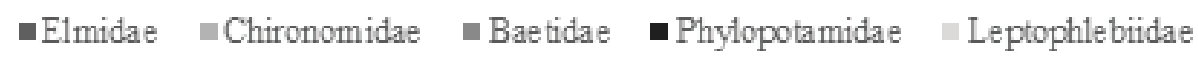

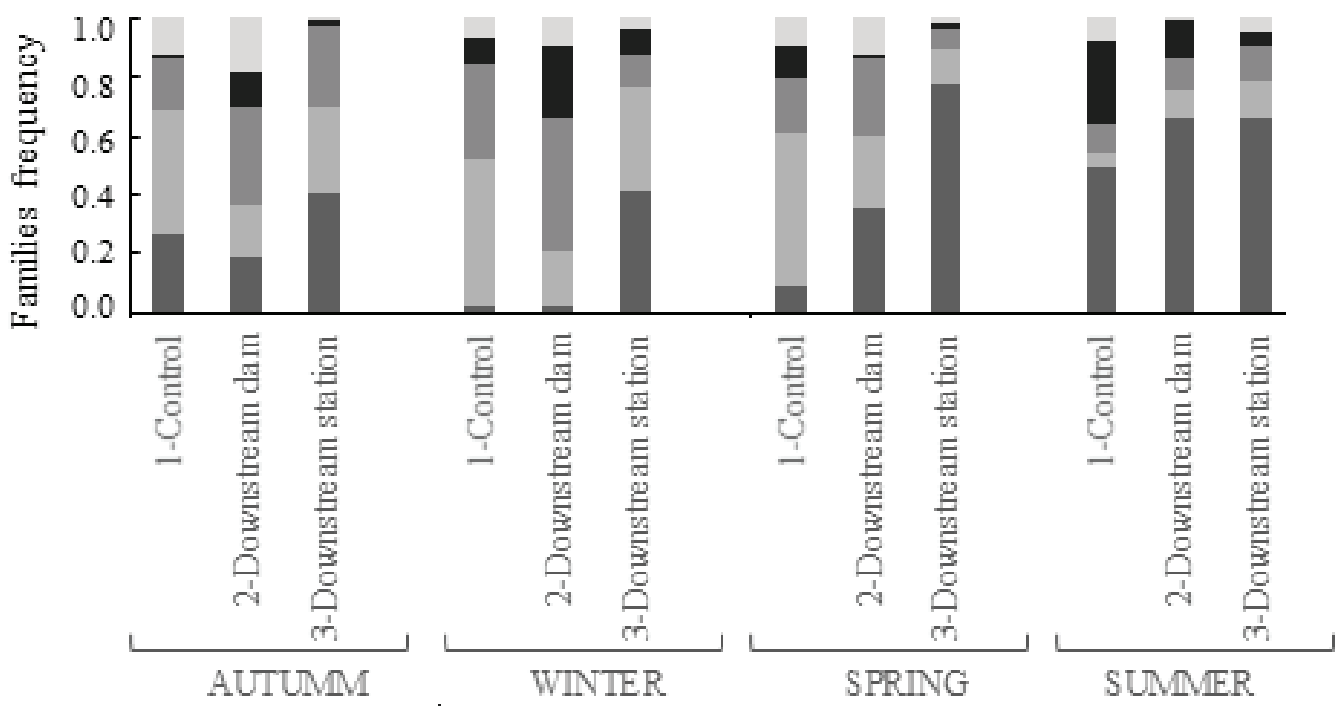

Figure 5. Representation of the 5 most frequent families by season and sampling site (control. dam area and downstream). Representación de las cinco familias más frecuentes según la época del año y el punto de muestreo: aguas arriba de la presa (control). zona de la presa. y aguas abajo de la presa.

a

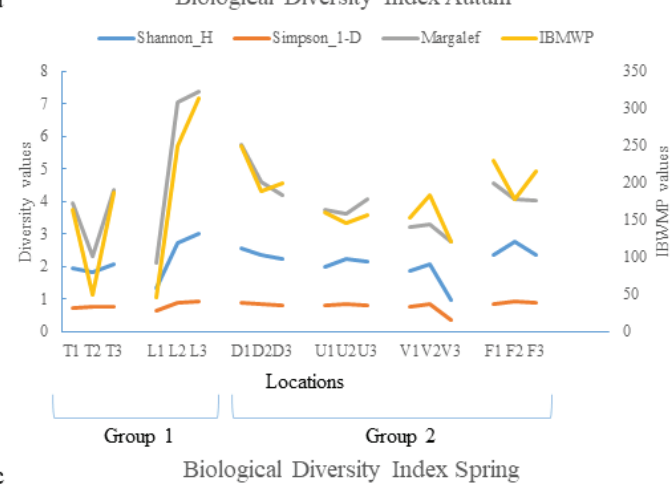

c

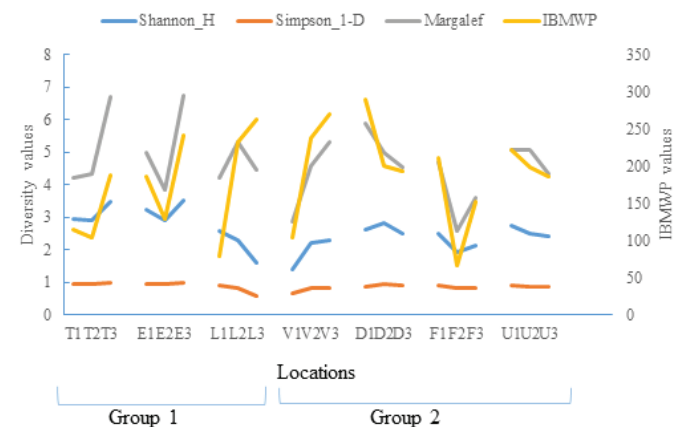

b

Biological Diversity Index Winter

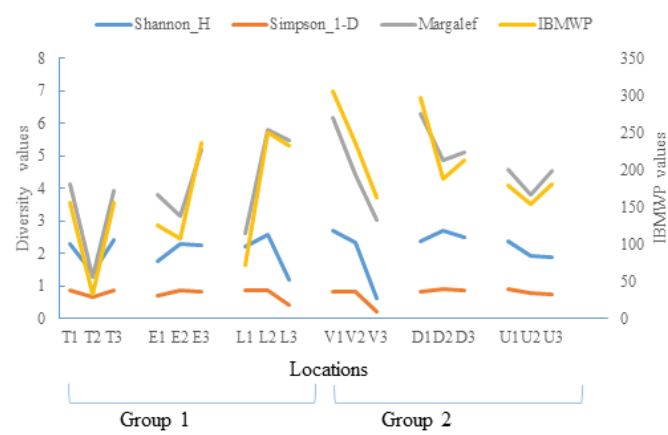

d

Biological Diversity Index Summer

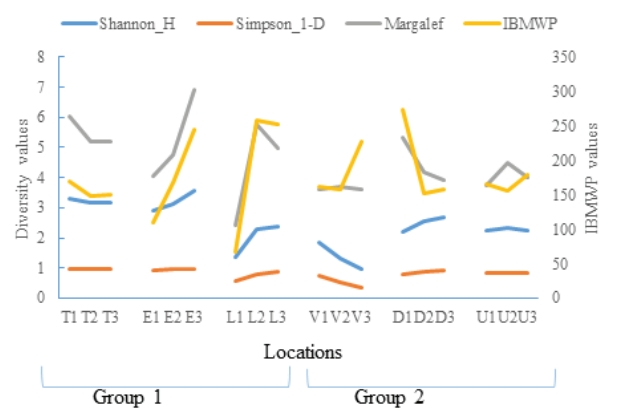

Figure 6. Metrics for 4 diversity indexes by seasons: autumn (a), Winter (b), spring (c) and summer (d). The segregation of the graph is done according to the river stations and groups 1 and 2. Métricas para 4 indices de diversidad por estaciones: otoño (a), invierno (b), primavera (c) y verano (d). La segregación del gráfico se realiza según los sitios de muestreo y los grupos 1 y 2. 
An nMDS analyses to compare the 3 sampling sites in each of the rivers (control, dam area and downstream) for each season produced inconclusive results, as only L3, located downstream in the Limia river was found to differ from the other sites.

The SIMPER analysis for the different seasons revealed different dissimilarity values for the macroinvertebrate communities: $51 \%$ between autumn and winter samples, $50 \%$ between winter and spring samples and $44 \%$ between spring and summer samples. This dissimilarity was mainly due to decrease in the mean abundance of taxa such as Chironomidae and Baetidae in autumn (Table 2). The SIMPER analysis for the different sites for the macroinvertebrate communities revealed $47 \%$ dissimilarity between control and dam area samples and $51 \%$ dissimilarity between dam area and downstream samples. This dissimilarity was mainly due to a decrease in the mean abundance of taxa such as Chironomidae in the dam area and the appearance of Ephemerellidae downstream (Table 2). Finally, the SIMPER analysis according to Group 1 (Tambre, Tea and Limia) and Group 2 (Deva-PO, Deva-OU, Fragoso and Tuño) rivers yielded $48 \%$ dissimilarity value for the macroinvertebrate communities. This dissimilarity was mainly due to a decrease in the mean abundance of taxa such as Chironomidae in Group 1 and a decrease in the abundance of Baetidae and the appearance of Ephemerellidae in Group 2 (Table 2).

Two-way PERMANOVA (Table 3) were tested to analyse whether there were differences between sites and seasons, between groups and seasons and between season and years. The matrix included all stations with all the data a

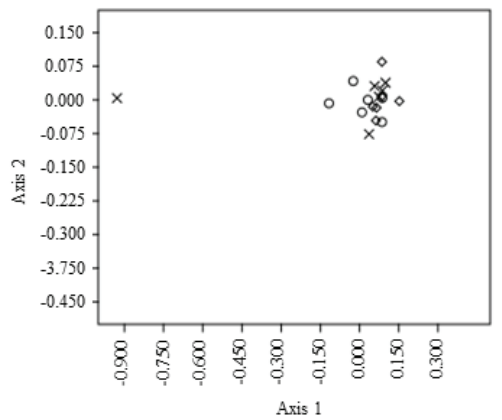

Autumm (stress level $22.76 \%$ )

$\mathrm{c}$

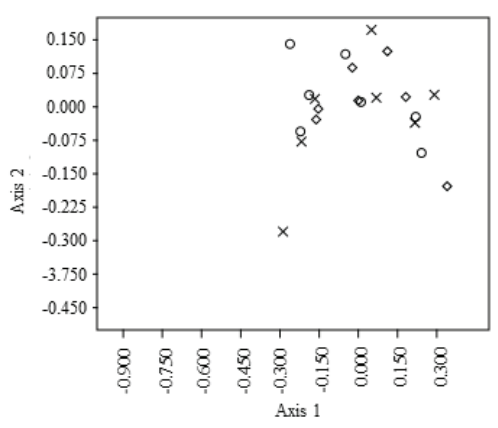

Spring (stress level $10.30 \%$ ) b

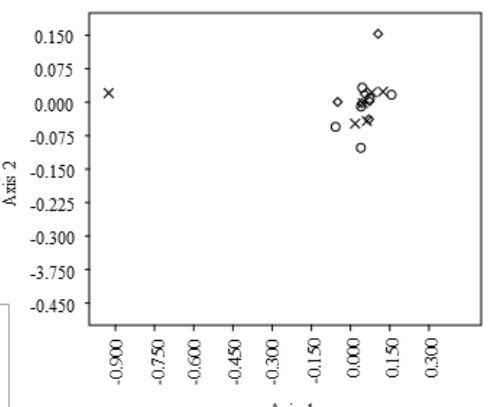

Axis 1

Downstream sites

d

Winter (stress level $15.60 \%$ )

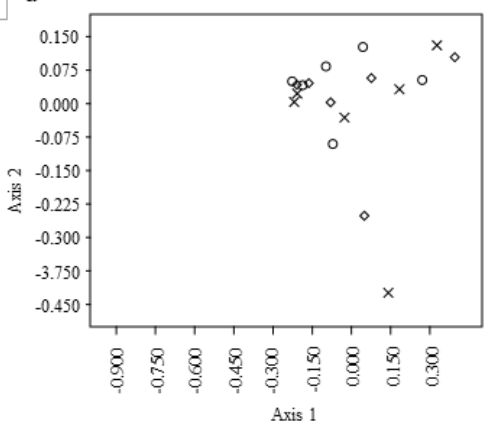

Summer (stress level $11.46 \%$ )

Figure 7. The nMDS plots by seasons [autumm (a), winter (b), spring (c) and summer (d)] and sampling sites (control, dam area and downstream). Axis 1 is coordinate 1 and axis 2 is coordinate 2 from nMDS. The cross represents the control sites, circle represents dawn area and diamond represents downstream sites. Los gráficos nMDS son por estaciones [otoño (a), invierno (b), primavera (c) y verano (d)] y por sitios de muestreo (control, área de presa y aguas abajo). El eje 1 es la coordenada 1 y el eje 2 es la coordenada 2 de nMDS. La cruz representa los sitios de control, el círculo representa el área de la presa y el diamante representa los sitios aguas abajo. 
Table 2. Average abundance and percentage contributions to similarity of the different macroinvertebrate families by season, sampling site and river groups 1 and 2. Abundancia media y porcentaje de contribución de la similitud para las diferentes familias de macroinvertebrados, estaciones del año, puntos de muestreo y grupo de rio 1 y 2.

\begin{tabular}{|c|c|c|c|}
\hline Families & \multicolumn{2}{|c|}{ Average abundance } & \multirow[t]{2}{*}{ Contribution to similarity $\%$} \\
\hline Season & Autumn & Winter & \\
\hline Average dissimilarity & $51 \%$ & & \\
\hline Chironomidae & 185.00 & 326.00 & 16.35 \\
\hline Baetidae & 172.00 & 249.00 & 13.17 \\
\hline Elmidae & 189.00 & 121.00 & 10.94 \\
\hline Limnephilidae & 63.80 & 178.00 & 5.50 \\
\hline Enchytraeidae & 34.50 & 54.90 & 4.00 \\
\hline Hydropsychidae & 71.70 & 36.80 & 3.64 \\
\hline Brachycentridae & 71.50 & 13.90 & 3.51 \\
\hline Simuliidae & 66.90 & 29.40 & 3.33 \\
\hline Leuctridae & 76.00 & 5.43 & 3.21 \\
\hline Season & Winter & Spring & \\
\hline Average dissimilarity & $50 \%$ & & \\
\hline Chironomidae & 326.00 & 341.00 & 15.76 \\
\hline Baetidae & 249.00 & 217.00 & 12.04 \\
\hline Ephemerellidae & 32.40 & 892.00 & 8.10 \\
\hline Elmidae & 121.00 & 167.00 & 7.26 \\
\hline Limnephilidae & 178.00 & 16.90 & 4.38 \\
\hline Enchytraeidae & 54.90 & 49.80 & 4.33 \\
\hline Simuliidae & 29.40 & 106.00 & 3.59 \\
\hline Leptophlebiidae & 20.30 & 84.40 & 3.24 \\
\hline Season & Spring & Summer & \\
\hline Average dissimilarity & $44 \%$ & & \\
\hline Chironomidae & 341.00 & 751.00 & 17.79 \\
\hline Ephemerellidae & 892.00 & 211.00 & 8.76 \\
\hline Baetidae & 217.00 & 122.00 & 6.74 \\
\hline Simuliidae & 106.00 & 198.00 & 5.44 \\
\hline Elmidae & 167.00 & 142.00 & 5.01 \\
\hline Dytiscidae & 16.40 & 62.20 & 4.58 \\
\hline Leptophlebiidae & 84.40 & 22.50 & 3.09 \\
\hline
\end{tabular}


Table 2. (cont.)

\begin{tabular}{|c|c|c|c|}
\hline Sampling site & Control & Dam area & \\
\hline Average dissimilarity & $47 \%$ & & \\
\hline Chironomidae & 466.00 & 204.00 & 16.19 \\
\hline Baetidae & 155.00 & 218.00 & 10.57 \\
\hline Elmidae & 106.00 & 162.00 & 8.04 \\
\hline Simuliidae & 159.00 & 44.50 & 4.40 \\
\hline Leptophlebiidae & 49.40 & 63.30 & 3.59 \\
\hline Leuctridae & 61.30 & 22.50 & 3.26 \\
\hline Enchytraeidae & 44.30 & 27.10 & 3.14 \\
\hline Phylopotamidae & 4.57 & 147.00 & 3.09 \\
\hline Gammaridae & 18.50 & 23.20 & 2.96 \\
\hline Sampling site & Dam area & & \\
\hline Average dissimilarity & $51 \%$ & & \\
\hline Chironomidae & 204.00 & 533.00 & 17.03 \\
\hline Baetidae & 218.00 & 197.00 & 10.56 \\
\hline Elmidae & 162.00 & 197.00 & 9.07 \\
\hline Ephemerellidae & 108.00 & 745.00 & 7.25 \\
\hline Simuliidae & 44.50 & 96.90 & 3.89 \\
\hline Limnephilidae & 9.00 & 154.00 & 3.54 \\
\hline Hydropsychidae & 47.20 & 148.00 & 3.33 \\
\hline Phylopotamidae & 147.00 & 52.30 & 3.18 \\
\hline Enchytraeidae & 27.10 & 58.30 & 3.05 \\
\hline Rivers & Group 1 & Group 2 & \\
\hline Average dissimilarity & $48 \%$ & & \\
\hline Chironomidae & 224.00 & 534.00 & 17.10 \\
\hline Baetidae & 203.00 & 180.00 & 10.18 \\
\hline Elmidae & 168.00 & 145.00 & 8.30 \\
\hline Ephemerellidae & 634.00 & 40.10 & 5.69 \\
\hline Simuliidae & 29.80 & 153.00 & 4.14 \\
\hline Hydropsychidae & 133.00 & 38.90 & 3.20 \\
\hline Limnephilidae & 123.00 & 22.40 & 3.20 \\
\hline Leuctridae & 53.90 & 48.20 & 2.91 \\
\hline
\end{tabular}


together in the study. Significant seasonal patterns were found $(p>0.05)$, and also significant differences among groups $(p<0.05)$ were found too. The two-way PERMANOVA test was also run for annual effect, finding significant difference $(p<0.05)$ among years.

\section{DISCUSSION}

As can be seen from the data abundance of individuals obtained in this study (Fig. 3), the benthic macroinvertebrates of the studied rivers were highly abundant (Rosenberg \& Resh, 1993). We found significant differences in terms of the abundance of individuals between the seasons of the year, seasonality in aquatic macroinvertebrate communities, which has also been demonstrated for a wide variety of climatic regions, from glacier-fed streams to the humid tropics (Béche $e t$ al., 2006). This seasonality is often the result of weather variations (Butler, 1984) and seasonal climate patterns (precipitation and insolation) that determine flow and temperature changes in aquatic systems, which, in turn, greatly influence the emergence, reproduction and development of many aquatic macroinvertebrates (Butler, 1984). The fact that we obtained higher values of abundance in spring is explained mainly by the taxa and their life cycle characteristics, as the number of larvae and nymphs appearing in spring in freshwater ecosystems will hatch to adults in summer (Óscoz et al., 2006).

Apart from the differences explained by seasonal changes, there are other differences in

Table 3. Two-way PERMANOVA tests for total abundance of individuals found in all sites considering as factors: location $\mathrm{x}$ season (with location corresponding to upstream - dam - downstream sites); groups x season and years x season. Análisis Permanova de la abundancia total para determinar la abundancia total de individuos encontrados en todos los sitios, considerando como factores (1) localización x estacionalidad, con la localización correspondiente a los sitios aguas arriba-presa-aguas abajo. (2) grupos x estacionalidad. (3) años x estacionalidad.

\begin{tabular}{lrrlll} 
Source (Location x Season) & SS & df & MS & F & p \\
\hline Location & 0.619 & 2 & 0.310 & 0.815 & 0.720 \\
Season & 2.048 & 3 & 0.683 & 1.796 & $* 0.005$ \\
Interaction & 0.783 & 6 & 0.131 & 0.343 & 1.000 \\
Residual & 27.365 & 72 & 0.380 & & \\
Total & $\mathbf{3 0 . 8 1 5}$ & $\mathbf{8 3}$ & & & \\
Source (Group x Season) & $\mathbf{S S}$ & $\mathbf{d f}$ & $\mathbf{M S}$ & $\mathbf{F}$ & $\mathbf{p}$ \\
\hline Season & 1.996 & 3 & 0.665 & 1.914 & $* 0.0012$ \\
Group & 1.988 & 1 & 1.988 & 5.718 & $* 0.0001$ \\
Interaction & 0.234 & 3 & 0.078 & 0.224 & 0.0005 \\
Residual & 26.431 & 76 & 0.347 & & \\
Total & $\mathbf{3 0 . 6 5 1}$ & $\mathbf{8 3}$ & & & \\
Source (Years x Season) & $\mathbf{S S}$ & $\mathbf{d f}$ & $\mathbf{M S}$ & $\mathbf{F}$ & $\mathbf{p}$ \\
\hline Years & 8.8337 & 6 & 1.4723 & 2.2632 & $* 0.0001$ \\
Season & 2.0481 & 3 & 0.68269 & 1.0494 & $* 0.0002$ \\
Interaction & -16.497 & 18 & -0.9165 & -1.4088 & 0.0028 \\
Residual & 36.43 & 56 & 0.65054 & & \\
Total & 30.815 & 83 & & &
\end{tabular}

* Significantly differed $(p<0.05)$ 
the communities. As some authors have pointed out (Ligon et al., 1995; Poff et al., 1997), this may be due to the impact of hydropower stations on rivers, which may cause alterations in the natural flow regime, channel platforms, habitats and sediment dynamics. The impact of the operation of the small hydroelectric power plant is felt differently in the fragments situated between the dam site and in the fragments situated downstream of them (Jesús et al., 2004) and similar impact is also observed in our study. Most sensitive taxa tend to be reduced in line with the frequency and intensity of disturbances (Prat et $a l ., 2009)$, to generally be replaced by more tolerant or better adapted taxa (Benítez-Mora \& Camargo, 2014).

Diversity, calculated using a variety of indexes and metrics (Fig. 6), was quite similar for the 2 river groups (group 1 and group 2) in spring, but different in summer, mainly due to low diversity in the Limia river at the control site (L1). One possible explanation is that the summer heat and greater water scarcity especially affected that basin; another is land use, as the riparian forest is more reduced along that river (Calapez et al., 2014). The highest diversity values were measured for the Tea river in spring and summer, possibly explained by its more diverse habitats and the better conditions provided by the riparian forest. It is known that torrentiality and seasonality showed a clear positive effect on diversity. Due to the presence of the dam and its operation, downstream there is a reduction in peak flows that typically creates more uniform and less dynamic habitats immediately below dams, affecting macroinvertebrate diversity (especially of sensitive and native species) and increasing primary production (Lobera et al., 2016). There were more notable differences among the 2 groups in results in diversity in autumn and winter. The diversity reduction may be due to the elimination of individuals which do not possess forms of fixation or which were dragged with the substrate (Jesús et al., 2004).

In our study, the abundance variations of the most sensitive families seem to follow a specific pattern, in this way distributions changed only according to the season in which they were sampled. The middle and lower sections of the rivers generally harboured taxa that were more tolerant to environmental disturbances (Rosenberg \& Resh, 1993, Benítez-Mora \& Camargo, 2014), coinciding with the findings for autumn (Fig. 4) where the results show a low percentage of sensitive families while recovering. In contrast, in winter and spring, the highest values for sensitive families were downstream of hydropower stations. Some authors (Anderson et al., 2015; Feld et al., 2014) suggest that these phenomena may be due to increased diversity of habitats associated with human alterations, because of the provision of habitat space, food and protection affecting the distribution and abundance of lotic invertebrates (Álvarez-Troncoso et al., 2015). By contrast in summer, sensitive families featured mostly in the middle part of the rivers, corroborating the study by Buss et al. (2004), stating that, in summer sampling, due to the gradient of water flow, the abundance and diversity of families was higher in areas closer to the dam than for other areas. This can be explained that in some areas upstream dam the communities are too close to the dam to be characterized by lentic conditions rather than lotic which also gives plenty of different options for microhabitats and diversity.

Downstream is different and some studies (Lobera et al., 2015 \& Lobera et al., 2016;) remarked that there is an effect that may be found downstream from dams with high sediment loads and low competent flood events resulting in fine sediment accumulation; this aggradation reduces taxa richness, diversity and macroinvertebrates density, and only high sediment- tolerant species may increase. Analysing possible diversity, abundance and distribution patterns in the taxa identified, we found some interesting information regarding distribution one family, Chironomidae. This is a Diptera family with general highly abundant and diversity, including genera and species with different ecological requirements, gathering both sensitive and tolerant taxa. They are usually identified to the family level because it is very demanding to identity their larvae, however they constitute often more than $50 \%$ of invertebrates' abundance. Regarding the results, we found in SIMPER analysis, presented in Table 2, Chironomidae were always highly represented, as those 
that contribute to higher similarities between groups. Chironomidae was very abundant in all the sites (Fig. 5) during the whole year except in summer where Elmidae is more dominant and Chironomidae is a residual group. Therefore, there is a potential use of Chironomidae as bioindicators in the evaluation of small dam disturbances, mainly in spring because the pattern is very clear and they are more abundant in the control sites and less abundant in the dam and downstream. Autumn conditions were more homogeneous among regions. Patterns would be less distinct than spring patterns because the presence of floods in autumn is universal along the gradient.

Aquatic macroinvertebrates have been found sensitive to changes in their environment, a feature that has been proven useful in the pursuit to find indicators of environmental conditions. In this study of the possible impact of small-scale hydropower stations on macroinvertebrate communities, especially in the dam area site, we analysed the families only present in upstream sites and IBWMP families that were only present in autumn, because this is considered a recovery period from summer. As a result of this study, Chloroperlidae and Beraeidae seem to be more sensitive to the presence of the dam and the flow alteration. They both are very particular families, where Beraeidae prefers small current sites and fountains and Chloroperlidade lives in specific substrate as fine to medium-sized gravel or coarse gravel to hand-sized cobbles (Graf et al., 2009; Graf et al., 2019). This two families were very abundant in control sites and low frequent in the dam area site. Goeridae family also reduces its presence in downstream site due to its preference for high speed water and in the case of Glossomatidae, by contrary, was more abundant in dam area than in the other sites. Our findings suggest that gradual loss of habitat specialists or taxa otherwise sensitive to hydromorphological alteration were almost balanced by gradual gains of more tolerant (ubiquituous) taxa (Feld et al., 2014) as for example Chironomidae, Baetidae or Elmidae.

Regarding the seasonality, another interesting pattern is given by the nMDS (Fig. 7), in autumn (Fig. 7a) and winter (Fig. 7b) communities tend to be very close to each other, indicating that probably spring (Fig. 7c) and summer (Fig. 7d) would challenge communities in some way, making them further apart, and both seasons are similar, showing the smallest average dissimilarities (44 $\%$ ). Probably both spring and summer (warmer seasons) could be the most challenging seasons for the communities segregating them apart. In the current climate change scenario, the presence of small dams could be a determinant disturbance changing invertebrate communities, segregating them apart considering for example the relative location of the dam.

The macroinvertebrate community assemblages differed in their patterns when we compared sites and seasons and groups and seasons and also differed among years. Thus, the seasons had significant impact on abundance.

There are significant differences among different years of the study and variation according to the PERMANOVA results (Table 3). Also, annual variation is considered as an explanation of part of the results (especially in spring, because some years were drier than others). The sampling years might have been influenced also by precipitation where flow regulation pattern may be much more problematic in drought years, and where the precipitation plays a very important role. The results show significant differences among years (Table 2). In terms of dissimilarity values (Table 1), the proportion of more sensitive families did not reach even $51 \%$ of the total. In winter, spring and summer there was a steady increase in these communities from the head of the river to downstream, while the opposite occurred in autumn. In general, there was not enough evidence to determine that small hydropower stations negatively affected the most sensitive macroinvertebrate communities.

The analysis of the possible impact of seasons or sites revealed differences in macroinvertebrate community compositions, and shows great variability within groups. The possible impact of hydropower stations on macroinvertebrate communities were not conclusive; only L3, located downstream of the Limia river dam, was found to behave differently from the other stations (Fig. 6).

The structural assessment measures using taxonomic composition used in our study, could potentially be complemented by other kinds of information that indirectly provide information 
on the ecological functioning of aquatic systems, e.g., habitat composition, riparian conditions, land use, river pressures and trait-based metrics (body size, life cycle duration, dispersal ability and respiration type) (Dolédec \& Statzner, 2010), which could also yield more accurate insights into the assessment of extreme events such as droughts. More studies are required to monitor continuously the effects of small dams in these upstream-downstream communities. We opine that testing the use of Chironomidae at a higher level of taxonomic resolution in the understanding of dam-related disturbance will imply some knowledge improvement in this region, especially during the spring season.

Some studies state that cold-water discharges in summer can slow down the growth rates of invertebrates (Haidekker, 2005), while some state that warm water discharges in winter can speed up the metabolic rate of aquatic insects, as a result of which they develop and emerge out of the appropriate season (Haidekker, 2005). The importance of mean temperature conditions in specific time periods or seasons has been shown to affect the growth rate, size and emergence of larvae and adult invertebrates. Thus, winter temperatures have been shown to be important for the growth rate of spring-emerging Plecopteran species, whereas summer temperatures have been identified to be important for the emergence timing of Ephemeropteran species (Haidekker, 2005).

\section{CONCLUSION}

Our findings point to differences in macroinvertebrate abundance and richness in aquatic systems impacted by hydropower stations and to a recovery process downstream, where the water level and habitats are not negatively affected by these stations. These differences were influenced by a seasonal component, with macroinvertebrate communities that were differently affected depending on the time of year. We also detected changes in assemblages upstream and downstream of stations with seasonal influences leading to new macroinvertebrate community compositions which may be due to the impact of the hydropower stations. More studies are essential to better understand the potential negative impact of small hydropower stations on freshwater ecosystems, and especially focussing on how the flow regime is affected. It would be especially interesting to determine the number of days in a year when flow is lower than stipulated by ORDER ARM/2656/2008, of 10 September, approving the hydrological planning instruction (BOE, 2008) as a consequence of the existence of a small hydropower station.

\section{ACKNOWLEDGEMENTS}

The authors thank the anonymous reviewers and editor for revising the manuscript and for their valuable suggestions. This study was supported by the Spanish Ministry of Education (Project: Developing a methodology for the environmental monitoring of small hydroelectric power stations using invertebrate fauna).

\section{REFERENCES}

ABBASI, T. \& S. A. ABBASI. 2011. Small Hydro and the Environmental Implications of Its Extensive Utilization. Renewable and Sustanaible Energy Reviews, 15 (4): 2134-2143. DOI: 10.1016/j.rser.2010.11.050

ALBA-TERCEDOR, J. 1996. Macroinvertebrados acuáticos y calidad de las aguas de los ríos. IV Simposio del Agua en Andalucía (SIAGA), Almería, España 2: 203-213.

ALBA-TERCEDOR, J., I. PARDO, N. PRAT \& A. PUJANTE. 2005. Metodología para el establecimiento el Estado Ecológico según la Directiva Marco del Agua. Protocolos de muestreo y análisis para invertebrados bentónicos. Ministerio de Medio Ambiente. Madrid, España.

ÁlVAREZ-TRONCOSO, R., A. PÉREZ-BILBAO, A. B. SARR, C. J. BENETTI \& J. GARRIDO. 2014. Estudio faunístico de larvas de tricópteros (Insecta, Trichoptera) en ríos de la provincia de Ourense (Galicia, España). Boletín de la Asociación española de Entomología, 38: 223-255.

ÁlVAREZ-TRONCOSO, R., C. J. BENETTI, A. B. SARR, A. PÉREZ-BILBAO \& J. GARRIDO. 2015. Impacts of hydroelectric power stations on Trichoptera assemblages in four 
rivers in NW Spain. Limnologica, 53: 35-41. DOI: 10.1016/j.limno.2015.05.001 0075-9511 ÁlVAREZ-TRONCOSO, R., C. J. BENETTI, A. B. SARR \& J. GARRIDO. 2017. The microhabitat preferences of Trichoptera in four rivers of Northwest Spain. Marine and Freshwater Research, 68: 1686-1694. DOI: 10.1071/MF16246

ANDERSON, D., H. MOGGRIDGE, P. WARREN \& J. SHUCKSMITH. 2015. The impacts of "run-of-river" hydropower on the physical and ecological condition of rivers. Water and Environment Journal, 29: 268-276. DOI: 10.1111/wej.12101

ARMITAGE, P. D., MOSS, D., WRIGHT, J. F., \& FURSE, M. T. 1983. The performance of a new biological water quality score system based on macroinvertebrates over a wide range of unpolluted running-water sites. Water research, 17(3), 333-347. DOI: 10.1016/00431354(83)90188-4

BÉCHE, L. A., E. P. MCELRAVY, \& V. H. RESH. 2006. Long-term seasonal variation in the biological traits of benthic-macroinvertebrates in two Mediterranean-climate streams in California, USA. Freshwater Biology, 51(1): 56-75. DOI: 10.1111/j.1365-2427.2005. 01473.x

BENETTI, C. J., \& J. GARRIDO. 2010. The influence of water quality and stream habitat on water beetle assemblages in two rivers in northwest Spain. Vie et milieu, 60: 53-63.

BENETTI, CJ., A. PÉREZ-BILBAO \& J. GARRIDO. 2012. Ecological Water Quality, Water Treatment and Reuse. Macroinvertebrates as indicators of water quality in running waters: 10 years of research in rivers with different degrees of anthropogenic impacts. In: Ecological Water Quality-Water Treatment and Reuse. K. Voudouris \& D. Voutsa (eds.): 95-122, InTech. Croatia. DOI: 10.5772/32115

BENÍTEZ-MORA, A. \& J. A. CAMARGO. 2014. Ecological responses of aquatic macrophytes and benthic macroinvertebrates to dams in the Henares River Basin (Central Spain). Hydrobiologia, 728: 167-178. DOI: 10.1007/s10750-014-1816-6

BOLETÍN OFICIAL DEL ESTADO (BOE), 2008. ORDEN ARM/2656/2008, de 10 de septiembre, por la que se aprueba la instrucción de planificación hidrológica. MINISTERIO DE MEDIO AMBIENTE, Y MEDIO RURAL Y MARINO. Boletín número 229, 2008: 38472-38582.

BOLETÍN OFICIAL DEL ESTADO (BOE), 2016. Plan Hidrológico 2015-2021, Parte española de la Demarcación Hidrográfica del Miño-Sil. MINISTERIO DE MEDIO AMBIENTE, Y MEDIO RURAL Y MARINO. Boletín número 16: 2972 a 4301.

BONADA N., PRAT N., RESH V. H., STATZNER B. 2006. Developments in aquatic insect biomonitoring: A Comparative Analysis of Recent Approaches. Annual Review of Entomology, 51: 495-523. DOI: 10.1146/annurev. ento.51.110104.151124

BUSS, P. F., BAPTISTA, P. F., NESSIMIAN, J. L., AND M. EGLER. 2004. Substrate specifity, environmental degradation and disturbance structuring macroinvertebrate assemblages in neotropical streams. Hydrobiologia, 518, 179-188. DOI: 10.1023/B:HYDR.0000025067. 66126.1C

BUTLER M. G. 1984. Life histories of aquatic insects. In: The Ecology of Aquatic Insects. V.H. Resh \& D.M. Rosenberg (eds.): 24-55, Praeger. New York.

CALAPEZ, A. R, ELIAS, C. L., SALOMÉ, F., ALMEIDA P. AND M. J. FEIO. 2014. Extreme drought effects and recovery patterns in the benthic communities of temperate streams. Limnetica, 33 (2): 281-296. DOI: 10.23818/limn.33.22

CARBALLEIRA, A., C. DEVESA, R. RETUERTO, E. SANTILLÁN \& F. UCIEDA. 1983. Bioclimatología de Galicia. Fundación Pedro Barrié de la Maza. A Coruña., España.

CLARKE, K. R. \& R. M. WARWICK. 2001. Change in Marine Communities: An Approach to Statistical Analysis and Interpretation. Plymouth Marine Laboratory, Plymouth.

DOLÉDEC, S. \& B. STATZNER. 2010. Responses of freshwater biota to human disturbances: contribution of J-NABS to developments in ecological integrity assessments. Journal of the North American Benthological Society, 29: 286-311. DOI: 10.1899/08-090.1 
FELD, C. K., F. BELLO \& S. DOLÉDEC. 2014. Biodiversity of traits and species both show weak responses to hydromorphological alteration in lowland river macroinvertebrates. Freshwater Biology, 59: 233-248. DOI: 10.1111/fwb.12260

FERREIRA, J., J. PÁDUA, S. J. HUGHES, R. M. CORTES, S. VARANDAS, N. HOLMES \& P. RAVEN. 2011. Adapting and adopting River Habitat Survey: Problems and solutions for fluvial hydromorphological assessment in Portugal. Limnetica, 30(2), 0263-272. DOI: 10.23818/limn.30.20

FUENTES-BARGUES, J. L. \& P. S. FERRER-GISBERT. 2015. Selecting a small run-of-river hydropower plant by the analytic hierarchy process (AHP): A case study of Miño-Sil river basin, Spain. Ecological Engineering, 85: 307-316. DOI: 10.1016/j.ecoleng. 2015.10.020 0925-8574

FUNK, A., D. TRAUNER, W. RECKENDORFER \& T. HEIN. 2017. The Benthic Invertebrates Floodplain Index-Extending the assessment approach. Ecological Indicators, 79: 303-309. DOI: 10.1016/j.ecolind.2017.04.035

GARCIA-ROGER, E. M., M. M. SANCHEZMONTOYA, R. GOMEZ, M. L. SUAREZ, M. R. VIDAL-ABARCA, J. LATRON, M. RIERADEVALL \& N. PRAT. 2011. Do seasonal changes in habitat features influence aquatic macroinvertebrate assemblages in perennial versus temporary Mediterranean streams? Aqua Sci. DOI: 10.1007/s00027-0110218-3

GÖTHE, E. P., E. A. WIBERG-LARSEN, A. KRISTENSEN, A. BAATTRUP-PEDERSEN, L. SANDIN \& N. FRIBERG. 2015. Impacts of habitat degradation and stream spatial location on biodiversity in a disturbed riverine landscape. Biodiversity and Conservation, 24 (6): 1423-1441. DOI: 10.1007/s10531-0150865-0

GRAF, W., A. W. LORENZ, J. M. TIERNO DE FIGUEROA, S. LÜCKE, M. J. LÓPEZRODRÍGUEZ \& C. DAVIES. 2009. Distribution and Ecological Preferences of European Freshwater Organisms. Volume 2, Plecoptera in Schmidt-Kloiber, A. \& D. Hering (ed). Pensoft Publishers, Sofia, Moscow.
GRAF, W., A. W. LORENZ, J. M. TIERNO DE FIGUEROA, S. LÜCKE, M. J. LÓPEZRODRÍGUEZ, J. MURPHY \& A. SCHMIDTKLOIBER. 2019: Dataset "Plecoptera". www.freshwaterecology.info - the taxa and autecology database for freshwater organisms, version 7.0 (accessed on 04.07.2019).

HAMMER, Ø, D. A. T. HARPER \& P. D. RYAN. 2001. PAST: Paleontological statistics software package for education and data analysis. Palaeontologica Electronica, 4(1): 9 pp. http://palaeo-electronica.org/2001_1/past/ issue 1_01.htm

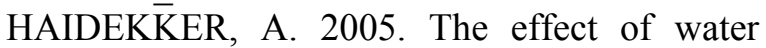
temperature regime on benthic macroinvertebrates: a contribution to the ecological assessment of rivers. Inaugural-Dissertation. Universität Duisburg-Essen, Germany.

JESUS, T., N. FORMIGO, P. SANTOS and G. R. TAVARES. 2004. Impact evaluation of the Vila Viçosa small hydroelectric power plant (Portugal) on the water quality and on the dynamics of the benthic macroinvertebrate communities of the Ardena river. Limnetica, 23: 241-256.

KRUSKAL, J. B. 1964. Nonmetric multidimensional scaling: a numerical method. Psychometrika, 29: 115-129.

KUCUKALI, S. \& K. BARIS. 2009. Assessment of small hydropower (SHP) development in Turkey: laws, regulations and EU policy perspective. Energy Policy, 37: 3872-3879. DOI: $10.1016 /$ j.enpol.2009.06.023

LIGON, F. K., W. E. DIETRICH \& W. J. TRUSH. 1995. Downstream ecological effects of dams. Bioscience, 45: 183-192. DOI: $10.2307 / 1312557$

ÓsCOZ, J., F. CAMPOS \& M. C. ESCA LA. 2006. Variación de la comunidad de macroinvertebrados bentónicos en relación con la calidad de las aguas. Limnetica, 25(3): 683-692.

PAISH, O. 2002. Micro-Hydropower: Status and Prospects. Proceedings of the Institution of Mechanical Engineers, Part A: Journal of Power and Energy, 216 (1): 31-40. DOI: 10.1243/095765002760024827.

PÉREZ ALBERTI, A. 1986. A Xeografia: o espacio xeográfico e o home. Ed. Galaxia. 
Vigo, España.

PÉREZ-BILBAO, A., C. J. BENETTI \& J. GAR-

RIDO. 2013. Estudio de la calidad del río

Furnia (NO España) mediante el uso de macroinvertebrados acuáticos. Nova Acta Cientifica Compostelana (Bioloxía), 20: 1-9.

LOBERA, G., P. BESNÉ, D. VERICAT, J. A. LÓPEZ-TARAZÓN, A. TENA, I. ARISTI, J. R. DÍEZ, A. IBISATE, A. LARRAÑAGA, A. ELOSEGI \& R. J. BATALLA. 2015. Geomorphic status of regulated rivers in the Iberian Peninsula. Science of the Total Environment, 508: 101-114.

LOBERA, G., I. MUÑOZ, J. A. LÓPEZ-TARAZÓN, D. VERICAT \& R. J. BATALLA. 2016. Effects of flow regulation on river bed dynamics and invertebrate communities in a Mediterranean river. Hydrobiologia, 784 (1), 283-304. DOI: 10.1007/s10750016-2884-6

POFF, N. L., J. D. ALLAN, M. B. BAIN, J. R. KARR, K. L. PRESTEGAARD, B. D. RICHTER, R.E. SPARKS \& J. C. STROMBERG. 1997. The natural flow regime. Bioscience, 47: 769-784. DOI: 10.2307/1313099

PLAN HIDROLÓXICO GALICIA-COSTA. 2015. RD 11/2016 do 8 de xaneiro. $D O G n^{\circ} 33$
PRAT, N., B. RÍOS, R. ACOSTA \& M. RIERADEVALL. 2009. Los macroinvertebrados como indicadores de calidad de las aguas. In: Macroinvertebrados bentónicos sudamericanos. E. Domínguez \& H.R. Fernández (ed.): 631-654. Fundación Miguel Lillo, San Miguel de Tucumán. Argentina.

ROSENBERG, D. M. \& V. H. RESH. 1993. Freshwater biomonitoring and benthic macroinvertebrates. Chapman \& Hall. Winnipeg. Canada.

SINGH, H., A. KUMAR \& N. KUMAR. 2015. Analysis and evaluation of small hydropower plants: A bibliographical survey. Renewable and Sustainable Energy Reviews, 51: 1013-1022. DOI: 10.1016/j.rser.2015.06.065.

TACHET, H., P. RICHOUX, M. BOURNAUD \& P. USSEGLIO-POLATERA. 2003. Invertébrés d'eau douce: Systématique, biologie, écologie. CNRS Editions. París. France.

URBANIČ, G. 2014. Hydromorphological degradation impact on benthic invertebrates in large rivers in Slovenia. Hydrobiologia, 1(729): 191-207. DOI: 10.1007/s10750-012-1430-4

WORLD ENERGY COUNCIL. 2010. Water for Energy. London, UK: WEC. ISBN: [978-0946121-10-6]. 